\title{
Investigation of genotoxic effects of inhalative occupational exposure to vanadium: results of a multiple endpoint study
} Veronika Ehrlich ${ }^{1}$, Armen Nersesyan ${ }^{1}$, Christine Hoelzl ${ }^{1}$, Franziska Ferk ${ }^{1}$, Julia Bichler ${ }^{1}$, Kambis Atefie ${ }^{1}$, Eva Valic ${ }^{2}$, Andreas Schaffer ${ }^{3}$, Rolf SchulteHermann ${ }^{1}$ and Siegfried Knasmüller*1

\author{
Address: ${ }^{1}$ Institute of Cancer Research, Department of Medicine I, Medical University of Vienna, Austria, ${ }^{2}$ Austrian Social Insurance for \\ Occupational Risks (AUVA), Vienna, Austria and ${ }^{3}$ Department of Medicine II, Medical University of Vienna, Austria \\ Email: Siegfried Knasmüller* - siegfried.knasmueller@meduniwien.ac.at \\ * Corresponding author
}

from 13th Scientific Symposium of the Austrian Pharmacological Society (APHAR). Joint Meeting with the Austrian Society of Toxicology (ASTOX) and the Hungarian Society for Experimental and Clinical Pharmacology (MFT)

Vienna, Austria. 22-24 November 2007

Published: 14 November 2007

BMC Pharmacology 2007, 7(Suppl 2):A60 doi:10.1 I86/I47|-22I0-7-S2-A60

This abstract is available from: http://www.biomedcentral.com/I47I-22/0/7/S2/A60

(c) 2007 Ehrlich et al; licensee BioMed Central Ltd.

Animal experiments showed that inhalative exposure to vanadate causes lung cancer. To assess DNA damage in exposed workers (EW, $\mathrm{n}=52$ ) of a metal factory, we monitored DNA migration and formation of micronuclei in blood cells of EW, who are exposed to vanadium pentoxide via inhalation and in a matched control group (CG, $\mathrm{n}$ $=54$ ). Median level of vanadium serum concentrations of EW $(2.23 \mu \mathrm{g} / \mathrm{l})$ was found to be 7 -fold increased compared to CG $(0.31 \mu \mathrm{g} / \mathrm{l})$. In the standard single cell gel electrophoresis (SCGE) assay with leucocytes, no differences were detected between EW and CG, but increased levels of oxidised DNA bases (detected with FPG and ENDO III) were found ( $\mathrm{p}<0.05)$. Pretreatment of leukocytes with bleomycin resulted in a higher extent of DNA migration $(27 \%, \mathrm{p}<0.001)$ and reduced capacity of DNA repair (by $42 \%, \mathrm{p}<0.001$ ) in EW. Furthermore, the cytochalasin blocked micronucleus (CBMN) assay was carried out with peripheral lymphocytes ( $\mathrm{n}=24$ per group). EW showed a 2.5 -fold higher MN frequency as CG and a 7 fold increase of nucleoplasmic bridges (which reflect formation of dicentric chromosomes) was seen. Nuclear buds (attributable to gene amplification events) were 3fold higher in EW ( $\mathrm{p}<0.001$ for all events). Apoptosis rates did not differ significantly between the two groups, whereas necrosis rates doubled in EW $(p<0.001)$. Taken together, our results show increased genetic damage in individuals which inhale vanadium dust, possibly indicating increased risk for cancer.

\section{Acknowledgements}

This project was financed by a grant from the Austrian Social Insurance for Occupational Risks (AUVA), Vienna, Austria. 